\title{
Revisioning Aleksandrov's Circus: Seventy Years of the Great Family
}

Alexander V. Prokhorov

College of William \& Mary, axprok@wm.edu

Follow this and additional works at: https://scholarworks.wm.edu/aspubs

Part of the Film and Media Studies Commons, and the Slavic Languages and Societies Commons

\section{Recommended Citation}

Prokhorov, Alexander V., Revisioning Aleksandrov's Circus: Seventy Years of the Great Family (2007). The Russian Review, 66(1), 1-4.

https://doi.org/10.1111/j.1467-9434.2006.00426.x

This Article is brought to you for free and open access by the Arts and Sciences at W\&M ScholarWorks. It has been accepted for inclusion in Arts \& Sciences Articles by an authorized administrator of W\&M ScholarWorks. For more information, please contact scholarworks@wm.edu. 


\title{
Revisioning Aleksandrov's Circus: Seventy Years of the Great Family
}

\begin{abstract}
ALEXANDER PROKHOROV
This introduction provides both a cultural context and a conceptual framework for the following articles on Grigorii Aleksandrov's Circus (Tsirk 1936) by Beth Holmgren and Rimgaila Salys. While delineating some basic background, the introduction will occasionally confront several polemical questions related to the place of Stalinist film in international cinema as well as in the Stalinist myth-making industry.

The authors chose for their discussion perhaps one of the most studied Soviet films and, through the prism of cultural studies approaches, amplified our sense of the Stalinist classic while rescuing it from the more traditional Cold War readings. Both articles focus on the issues of gender and body politics in Stalinist cinema. They also wrest the discussion of Stalinist musical comedy from the familiar confines of comparison and contrast with Hollywood musicals. Instead, they contend that Aleksandrov profited from his knowledge of and creative exchange with international modernist culture such as German popular cinema and Art Deco as the international style of architectural, industrial, and consumer goods' design.

Relying on cultural theory, Holmgren argues for the pivotal role of Aleksandrov's film in Soviet culture. ${ }^{1}$ While Western musicals offered utopian solutions to domestic social ills, Circus inaugurated a Stalinist final solution to the social ills of capitalism while cunningly deflecting attention from the contradictions and issues of Stalinist society: Circus "offer[s] strictly Soviet-based solutions to the Western social inadequacies that Western entertainment abets or represses." Holmgren investigates how the filmmaker exploits a tale of gender and racial emancipation to naturalize Soviet communal identity, including gender, ethnic, and racial hierarchies as an integral part of that identity. Most importantly, Holmgren frames her analysis of gender and racial identity politics in Aleksandrov's picture within contemporary cultural theory, rather than the tired rhetoric of the Cold War.
\end{abstract}

\section{Dedicated to the memory of Sergei Dobrotvorskii}

'Richard Dyer, "Entertainment as Utopia," in Cultural Studies Reader, ed. Simon During (London, 1993), 271-83; Jane Feuer, The Hollywood Musical, $2^{\text {nd }}$ ed. (Bloomington, 2002); Arthur Knight, Disintegrating the Musical: Black Performance and American Musical Film (Durham, 2002).

${ }^{2}$ See, in this issue of Russian Review, Beth Holmgren, "The Blue Angel and Blackface: Redeeming Entertainment in Alexandrov's Circus," 22.

The Russian Review 66 (January 2007): 1-4

Copyright 2007 The Russian Review 
Salys employs Lucy Fischer's feminist reading of Art Deco's gender assumptions to examine how Stalinist cultural producers, Aleksandrov in particular, incorporated Art Deco techniques into the visual regime of High Stalinism. ${ }^{3}$ Post-Soviet cinema has paid ample tribute to the stylistic sophistication and coherence of Stalinist culture and its intertextual links with European modernism. Ivan Dykhovichnyi's Moscow Parade (Prorva; 1993) is perhaps most memorable example of this trend. Few scholars, however, have focused on the place and function of international design styles in Stalinist culture. And nobody, to my knowledge, has attempted a gynocentric reading of the role of Art Deco in Stalinist cinematic mise-en-scène. In this respect, by contextualizing Aleksandrov's musical in the international artistic and architectural trends of 1930s modernity, Salys offers a pioneering perspective on the picture, one that perhaps explains why this propaganda film impressed international audiences at the 1937 Paris World's Fair.

In his recent study of the legendary history of the October Revolution, Fred Corney contends that myth shapes people's understanding of past events, while "the narrative ... adds important dimensions to this conception of myth. It conveys the notion of dynamism and process, of a story told in the telling, replete with the sense of drama, coherence and flow shared by all well-told tales. Narrative form should not be dismissed as mere adornment but seen as a device that makes the story itself comprehensible." ${ }^{4}$ Seventy years after its release, Aleksandrov's Circus continues to captivate domestic viewers and to attract scholars' attention precisely because the director found a magic narrative formula for the key myths of Stalinist culture: the positive hero, the "Great Family" of nations, and the ideological clash between Soviet "us" and capitalist "them" as a dominant principle of totalitarian culture. In contrast to the fragmented, vaudeville-inspired aesthetics of Aleksandrov's first musical, Jolly Fellows (Veselye rebiata 1934), his second picture imparted a strong visual and narrative coherence not only to Stalinist but also to RussoSoviet cultural mythology long after Stalin's death. Hence post-Soviet viewers still enjoy the totalitarian classic on their small screens. Moreover, as David Branderberger argues in his discussion of Stalinist culture's influence on post-Soviet Russian national identity, Stalinist cinema, and Circus as one of its iconic texts, articulated a form of populism that continues to resonate among Russians today. ${ }^{5}$ The recent revival of neo-Stalinist populism under Putin's regime provides ample evidence of the resilience of cultural assumptions established by Stalinist culture, and cinema as its prime visual form.

Critics often examine Aleksandrov's Circus within the framework of Western genre and star systems-above all, the musical in its Hollywood or UFA incarnation, as transplanted to Soviet cinema. ${ }^{6}$ Soviet cultural administrators, however, were always

${ }^{3}$ Lucy Fischer, Designing Women: Cinema, Art Deco and the Female Form (New York, 2003).

${ }^{4}$ Fred Corney, Telling October: Memory and the Making of the Bolshevik Revolution (Ithaca, 2004$), 4$.

${ }^{5}$ David Branderberger, National Bolshevism: Stalinist Mass Culture and the Formation of Modern Russian National Identity (Cambridge, MA, 2002), 240-48.

${ }^{6}$ Moira Ratchford, "Circus of 1936: Ideology and Entertainment under the Big Top," in Inside the Soviet Film Satire: Laughter with a Lash, ed. Andrew Horton (New York, 1993), 83-93; Neia Zorkaia, "Tsirk i sverkaiushchie geroini Liubovi Orlovoi," in Krutitsia, vertitsia shar goluboi: Desiat'shedevrov sovetskogo kino (Moscow, 1998), 109-30. 
suspicious of commercial film genres because they implied capitalist profiteering as the prime goal of film production. While on the surface Circus looks and sounds like a commercial genre product, I would argue that Aleksandrov's film belongs to a different category of cultural text - namely, a propaganda film designed to frame a political event of major mythological significance, with music carrying much of the "message" and simultaneously rendering that message palatable. Made to celebrate the adoption of the Stalinist Constitution (1936) - the midpoint landmark from the October Revolution to the communist end of history-Circus was designed to bring visual coherence and narrative stability/legitimacy to the myth of the Soviet Union as a society living according to the rule of socialist law. In its focus on the grand teleology of creating the socialist family of nations, Circus resembles historical-revolutionary films produced for the anniversary of the October Revolution: they, too, visualized the current version of the foundation tale. Aleksandrov had learned from his work with Sergei Eisenstein on the production of October (1927), an anniversary film that arguably placed the Bolshevik party at the center of the story of the October Revolution. Politically, the legacy of Soviet montage cinema and collaboration with Eisenstein were appreciably more important for Aleksandrov than the experience he acquired in Hollywood. As Holmgren's article demonstrates, through a careful juxtaposition of attractions and symbols appropriated from Western films, Aleksandrov's Circus offers a biting critique of Western racism and gender and class exploitation while promoting the Soviet community as presumably immune to such social ills.

Among Aleksandrov's appropriations is the image, developed in Western cinema and avant-garde art, of the circus as a metaphor for the modern world. Out of numerous film narratives set against the backdrop of the big top, the 1928 film by Charles Chaplin, Aleksandrov's friend, provided one of the major inspirations. Like Chaplin, Aleksandrov mixes comedy with melodrama. However, if Chaplin comments on Western modernity via a narrative constantly balancing slapstick and melodrama, and favors melodramatic closure, Aleksandrov creates a diegesis that cleverly assigns the two genres to diametrically opposed ways of sociopolitical life: melodrama belongs to the prejudice-ridden capitalist "other," while comedy triumphs in the protagonist's redemption and introduction into the Soviet way of life. Whereas the synchronic formula of Chaplin's Circus is "comedy" interfused with "melodrama," Aleksandrov's Circus opts for a diachronic model, whereby "comedy" defeats and displaces "melodrama" in the course of the ideological war.

An introduction to a cluster of articles devoted to Aleksandrov's Circus would be incomplete without a few remarks about musicals' self-reflectivity. In her commentary on the Hollywood musical, Jane Feuer notes that film critics usually discuss self-reflectivity when analyzing avant-garde cinema. Yet self-reflectivity, she argues, is also a convention of such commercial genres as the musical:

Self-reflectivity as a critical category has been associated with films, such as those of Godard, which call attention to the codes constituting their own signifying practices. The term has been applied to aesthetically or politically radical films that react against so-called classical narrative cinema by interrogating their own narrativity. Thus we tend to associate reflexivity with 
the notion of deconstruction within filmmaking practice. The MGM musical, however, uses reflexivity to perpetuate rather than to deconstruct the codes of the genre. Self-reflective musicals are conservative texts in every sense. ${ }^{7}$

Aleksandrov appropriates the musical's self-referentiality to comment on the changing ideological regime of the Soviet film industry. Circus tells the story of the transition from an entertainment industry based on relative openness and collaboration with the Western, primarily German, entertainment industry, to the closed, self-reliant entertainment economy that caught up with and surpassed Western entertainment. Having won the ideological war and technological race with the West, Aleksandrov's victorious Soviet entertainers take as booty Westerners' women and children: both the American protagonist and her black child choose to stay in "Our Motherland" with the Soviet white man. As Lahusen demonstrates in his discussion of early Soviet talkies, the transition to sound in Soviet cinema coincided with the increasing political isolationism of Stalinist Russia and the revamping of the film industry along the lines of reliance on domestic film production, without using revenues from Western imports. ${ }^{8}$ In Circus, Aleksandrov perpetuated Stalinist ideological codes by means of the backstage musical's self-reflective conventions.

By giving gender and body-politics readings of Aleksandrov's classic, Holmgren and Salys uncover the contradictions and instabilities of the myth of Soviet gender equality. Their refreshing exploration of identity politics in Aleksandrov's film sheds light on the differences between Western and Soviet modernity and addresses the central question of the film's continuing cultural relevance at its seventieth anniversary.

August 2006

${ }^{7}$ Jane Feuer, “The Self-Reflexive Musical and the Myth of Entertainment," in Film Genre Reader, II, ed. Barry Keith Grant (Austin, 2003), 454.

${ }^{8}$ About the industrial and ideological role of comedy in Soviet cinema's transition from silent to synchronized sound film production see Thomas Lahusen, "From Laughter 'Out of Sync' to Post-Synchronized Comedy, or, How the Stalinist Film Musical Caught Up with Hollywood and Overtook It," in Socialist Cultures East and West: A Post-Cold War Reassessment, ed. Dubravka Juraga and M. Keith Booker (Westport, CT, 2002), 31-42. 